\title{
Działalność Państwowego Grona Konserwatorów Zabytków Prehistorycznych (1920-1928) na terenie województwa kieleckiego
}

\section{Activities of the State Group of Prehistoric Monuments Conservators (1920-1928) in the Kielce Voivodeship}

The times of the Second Polish Republic were a particularly important period in the development of Polish archeology, because after Poland regained independence, the first state institution was established to organize the protection of archaeological monuments throughout the country. It was the State Group of Prehistoric Monuments Conservators functioning in the years 1920-1928. Their activities in the Kielce voivodeship brought particularly interesting results. Conservators and delegates of the State Group of Prehistoric Monuments Conservators did a lot in the field of inventory and protection of archaeological monuments in the Kielce region, undertaking surface and excavation rescue research, as well as popularizing archeology among the inhabitants of the region. The result of their activities was the registration, discovery, and exploration of many archaeological sites, including such valuable ones as a complex of multicultural sites in Złota near Sandomierz and in Książnice Wielkie, and a unique complex of striped flint mines in Krzemionki near Ostrowiec. The sites discovered at that time in the Kielce voivodeship are still the subject of interest and research to Polish archaeologists.

Keywords: history of archaeology, protection of archaeological heritage, the Second Republic of Poland, Kielce Voivodeship

Słowa kluczowe: historia archeologii, ochrona zabytków archeologicznych, Il Rzeczypospolita Polska, województwo kieleckie

Czasy II Rzeczypospolitej to szczególnie ważny okres w rozwoju polskiej archeologii. Po powstaniu niepodległego państwa polskiego utworzono bowiem pierwszą instytucję państwową, która podjęła kwestię organizacji ochrony zabytków archeologicznych na obszarze całego kraju. Było to funkcjonujące w latach 1920-1928 Państwowe Grono 
Konserwatorów Zabytków Prehistorycznych (dalej PGKZP). Bardzo interesujące rezultaty przyniosła działalność PGKZP na obszarze ówczesnego województwa kieleckiego. Zaowocowała ona rejestracją, odkryciem i zbadaniem wielu stanowisk archeologicznych, w tym tak wartościowych jak kompleks wielokulturowych stanowisk w Złotej k. Sandomierza i Książnicach Wielkich oraz wyjątkowego zespołu kopalń krzemienia pasiatego w Krzemionkach k. Ostrowca. Praca ta ma na celu przypomnienie osiągnięć konserwatorów i delegatów PGKZ na omawianym terenie w zakresie inwentaryzacji oraz prób ochrony zabytków archeologicznych, podejmowania badań powierzchniowych i wykopaliskowych, a także popularyzacji archeologii i opieki nad zabytkami wśród mieszkańców Kielecczyzny, m.in. poprzez współpracę z regionalnymi stowarzyszeniami - oddziałami Polskiego Towarzystwa Krajoznawczego (dalej PTK).

Pierwszym krokiem w kierunku zorganizowania PGKZP było wydanie w dniu 31 października 1918 r. przez powołaną w 1917 r. na terenie Królestwa Polskiego Radę Regencyjną, dekretu O opiece nad zabytkami sztuki i kultury. Uczynił on zabytki archeologiczne własnością państwa oraz uzależnił prawo do prowadzenia wykopalisk zarówno na ziemi państwowej, jak i prywatnej, od zgody Ministerstwa Wyznań Religijnych i Oświecenia Publicznego ${ }^{1}$ (dalej MWRiOP), w którego kompetencjach znalazła się opieka i zawiadywanie wykopaliskami i znaleziskami archeologicznymi². Na skutek postulatów wybitnych ówczesnych archeologów, wśród których prym wiedli Włodzimierz Demetrykiewicz (1859-1937) i Włodzimierz Antoniewicz (1893-1973), przedstawionych w memoriale Polskiej Akademii Umiejętności $O$ organizację archeologii przedhistorycznej w Polsce skierowanym 12 czerwca 1919 r. do MWRiOP, ministerstwo zorganizowało konferencję polskich archeologów, której zwieńczeniem było sformułowanie „wytycznych państwowej organizacji ochrony zabytków przeddziejowych"3. Efektem tych propozycji i działań stało się powołanie w styczniu 1920 r. tymczasowego Prezydium PGKZP, które tworzyło trzech znanych archeologów: przewodniczący Erazm Majewski (1858-1922), wiceprzewodniczący Włodzimierz Antoniewicz i sekretarz Roman Jakimowicz (1991-1951)4. Przygotowało ono Projekt rozporządzenia Rady Ministrów $w$ sprawie utworzenia PGKZP zawierający m.in. propozycję wydzielenia na terenie Polski ośmiu tymczasowych okręgów konserwatorskich, zawiadywanych przez poszczególnych konserwatorów ${ }^{5}$, których MWRiOP mianowało wiosną 1920 r. Ziemie województwa kieleckiego znalazły się początkowo w granicach II okręgu południowo-warszawskiego oraz IV okręgu krakowskiego ${ }^{6}$, jednak w wyniku przeprowadzonej w 1922 r., korekty utworzono

1 B. Stolpiak, Rozwój prahistorii polskiej w okresie 20-lecia międzywojennego. Część l: 1918-1928, Poznań 1984, s. 36; M.M. Blombergowa, Opieka nad zabytkami archeologicznymi w Polsce do roku 1928, [w:] Tadeusz Roman Żurowski i konserwatorstwo archeologiczne w Polsce XX wieku, red. J. Wysocki, Z. Kobyliński, Warszawa 1999 , s. 125.

2 J. Wysocki, Konserwatorstwo archeologiczne w Polsce w latach 1920-1940, [w:] Tadeusz Roman Żurowski i konserwatorstwo archeologiczne w Polsce XX wieku, red. J. Wysocki, Z. Kobyliński, Warszawa 1999, s 133-134.

3 Organizacja ochrony zabytków przedhistorycznych w Polsce, "Wiadomości Archeologiczne” t. 5, 1920, z. 1-2, s. 77.

4 Tymczasowy skład Państwowego Grona Konserwatorów Zabytków Przedhistorycznych, „Wiadomości Archeologiczne" t. 5, 1920, z. 1-2, s. 82; M. Karczewski, Państwowe Grono Konserwatorów Zabytków Archeologicznych i Państwowe Muzeum Archeologiczne i ich rola w ochronie zabytków archeologicznych, "Seminare” t. 36, 2015, nr 4, s. 183-186; B. Stolpiak, op. cit., s. 38-40.

5 Projekt rozporządzenia ministra w sprawie utworzenia Państwowego Grona Konserwatorów Zabytków Prehistorycznych, „Wiadomości Archeologiczne” t. 5, 1920, z. 1-2, s. 78-79.

6 Tymczasowe Okręgi Konserwatorskie, „Wiadomości Archeologiczne” t. 5, 1920, z. 1-2, s. 83; Sprawozdanie z działalności Prezydjum Państwowego Grona Konserwatorów Zabytków Prehistorycznych w r. 1920, „Wiadomości Archeologiczne" t. 5, 1920, z. 3-4, s. 223. 
osobny okręg kielecki, a w miejsce krakowskiego powołano okręg zachodnio-małopolski. Organem wydawniczym PGKZP zostało wznowione po latach przerwy czasopismo „Wiadomości Archeologiczne" i to na jego łamach ukazywały się m.in. sprawozdania z działalności kierownictwa PGKZP i jego konserwatorów okręgowych. W kolejnych latach dwukrotnie następowała zmiana na stanowisku przewodniczącego PGKZP, którym w 1921 r. został Józef Kostrzewski (1885-1969), a w 1924 r. Roman Jakimowicz ${ }^{8}$.

Stojące przed konserwatorami okręgowymi zadania obejmowały: poszukiwania i rejestrację stanowisk archeologicznych oraz ich ochronę przed zniszczeniem, prowadzenie badań ratowniczych oraz popularyzację w społeczeństwie wiedzy archeologicznej. Funkcję konserwatora dla zabytków archeologicznych na okręg krakowski, a następnie (od 1922 r.) na okręg zachodnio-małopolski, obejmujące również południową część województwa kieleckiego, powierzono młodemu archeologowi Józefowi Żurowskiemu (1892-1936). Żurowski był absolwentem archeologii klasycznej i prehistorii na Uniwersytecie Jagiellońskim, który w 1921 r., już po objęciu funkcji konserwatora, został asystentem w Zakładzie Archeologii Przedhistorycznej UJ, kierowym przez Włodzimierza Demetrykiewicza. W tym samym roku ten wyjątkowo pracowity badacz objął również obowiązki pomocnika kustosza Muzeum Archeologicznego Polskiej Akademii Umiejętności (dalej MA PAU), które pełnił przeszło rok. W 1922 r. zdobył stopień doktora broniąc pracy Wykopalisko z Jakuszowic Małych na tle zabytków krajów ościennych ${ }^{9}$, a w 1928 r. habilitował się na tej samej uczelni na podstawie rozprawy Skarby halsztackiego okresu z doliny Dunajca ${ }^{10}$.

Natomiast stanowisko konserwatora dla zabytków archeologicznych na okręg południowo-warszawski, a od 1922 r. na okręg kielecki, objął Stefan Krukowski (1890-1982). Krukowski był archeologiem pozbawionym formalnego wykształcenia, w dużym stopniu samoukiem, aczkolwiek początki jego archeologicznych zainteresowań wiążą się z osobą Erazma Majewskiego, który w 1908 r. zatrudnił go w swoim prywatnym muzeum ${ }^{11}$. W momencie mianowania na stanowisko konserwatora PGKZP Krukowski był już badaczem wysoko cenionym za rozległa wiedzę dotyczącą głównie starszej epoki kamienia i praktyczne doświadczenie w prowadzeniu prac wykopaliskowych.

Ponadto Prezydium PGKZP mianowało na terenie województwa kieleckiego kilku swoich delegatów, których zadaniem było przekazywanie konserwatorom informacji o odkryciach archeologicznych i pomoc w prowadzeniu badań terenowych ${ }^{12}$. Najbardziej aktywnym z nich był Józef Pietraszewski ${ }^{13}$ (1885-1965), z zawodu architekt, a po-

7 Sprawozdanie z III Konferencji konserwatorów okręgowych, odbytej w Warszawie w dn. 24 i 25 czerwca 1922 r., „Wiadomości Archeologiczne" t. 7, 1922, s. 158.

8 A. Abramowicz, Historia archeologii polskiej. XIX i XX wiek, Warszawa-Łódź 1991, s. 114.

9 Archiwum Muzeum Archeologicznego w Krakowie [Archiwum MAK], Spuścizna Józefa Żurowskiego, Wykopalisko z Jakuszowic Małych na tle zabytków krajów ościennych (maszynopis).

10 R. Jakimowicz, Ś. p. Józef Żurowski, „Wiadomości Numizmatyczno-Archeologiczne” t. 17, 1935, s. 137-142; J. Kostrzewski, Wspomnienia o doc. Józefie Żurowskim, „Z Otchłani Wieków” t. 27, 1961, s. 34-36.

11 J. Wrońska, Początki działalności naukowej prof. Stefana Krukowskiego, [w:] Prof. Stefan Krukowski (18901982): Działalność archeologiczna i jej znaczenie dla nauki polskiej, red. J. Partyka, J. Lech, Ojców 1992, s. 44; S.K. Kozłowski, Stefan Krukowski. Narodziny giganta, Warszawa 2007, s. 26-41.

12 B. Stolpiak, op. cit., s. 55.

13 Zbiory cyfrowe Państwowego Muzeum Archeologicznego w Warszawie [ZC PMA], Spuścizna Stefana Krukowskiego, Korespondencja, Maszynopis - kopia pisma Państwowego Grona Konserwatorów Zabytków Przedhistorycznych (nr 191/21) do Józefa Pietraszewskiego z informacją o mianowaniu go Delegatem PGKZP na terenie województwa kieleckiego. Warszawa 21 XII 1921 r., sygn. PL PMA 1-1-2-12-8. 
nadto sekretarz oddziału Polskiego Towarzystwa Krajoznawczego (dalej PTK) w Sandomierzu ${ }^{14}$.

Badania archeologiczne na terenie Kielecczyzny podejmowali także działacze Grona z innych okręgów, w tym przede wszystkim kierownik PGKZP Roman Jakimowicz oraz delegat Zygmunt Szmit (1895-1929), z Drohiczyna, woj. białostockie, nauczyciel szkoły powszechnej i archeolog samouk, od 1926 r. asystent w organizowanym przy PGKZP Centralnym Muzeum Archeologicznym w Warszawie ${ }^{15}$. W wykopaliskach prowadzonych z ramienia PGKZP brał także udział asystent z MA PAU w Krakowie Tadeusz Reyman $(1899-1955)^{16}$. Ponadto działającym $w$ regionie konserwatorom pomagali studenci prehistorii, głównie z Uniwersytetu Warszawskiego i z Uniwersytetu Jagiellońskiego.

Początki aktywności PGKZP na terenie województwa kieleckiego związane były z działalnością konserwatora okręgu południowo-warszawskiego Stefana Krukowskiego. W 1920 r. dokonał on oględzin „otwartego stanowiska późno-neolitycznego" w Zbrzy Wielkiej pod Zawichostem, pow. sandomierski, „z krzemieniami dużemi, biało nakrapianemi"17, które mylnie przypisał kulturze ceramiki „gwiaździstej"18 (promienistej) ${ }^{19}$. Wskazówek dotyczących lokalizacji tego miejsca dostarczył konserwatorowi jego odkrywca Zdzisław Lenartowicz (1862-1941)20, malarz z zawodu i zapalony archeolog amator, odkrywca i badacz wielu innych stanowisk archeologicznych na Kielecczyźnie ${ }^{21}$. Badania na tym stanowisku prowadził później delegat PGKZP Józef Pietraszewski22, a w 1923 r. wizytowali je konserwator Józef Żurowski wraz z Pietraszewskim oraz z księdzem Andrzejem Wyrzykowskim (1879-1955), profesorem i opiekunem biblioteki Seminarium Duchownego w Sandomierzu. Zebrali oni wówczas w tego miejsca kilkanaście wyrobów krzemiennych i odpadków krzemienia szarego, biało nakrapianego (świeciechowskiego) oraz fragmenty naczyń ceramicznych ${ }^{23}$.

Ożywienie działań konserwatorów PGKZP nastąpiło w 1921 r., co związane było z przyznaniem Gronu stałego budżetu24. W tymże roku Prezydium PGKZP przydzieliło konserwatorom okręgowym bardziej szczegółowe zadania, na które miały się składać:

14 K. Załuska, Historia Muzeum w Sandomierzu, „Rocznik Muzeum Świętokrzyskiego” t. 5, 1968, s. 9-12.

15 S.K. Kozłowski, Muzeum, [w:] Stefan Krukowski i jego przygoda z PMA, red. S.K. Kozłowski, Warszawa-Łódź 2014, s. 22, 34, 56; J. Jaskanis, Wspomnienie o Zygmuncie Szmicie (1895-1929) - asystencie Państwowego Muzeum Archeologicznego w Warszawie, "Światowit” t. 42, 1999, s. 88-91.

16 Archiwum MAK, Spuścizna Tadeusza Reymana, Przebieg życia (maszynopis), s. 1-2, sygn. SP 30/3.

17 ZC PMA, Spuścizna Stefana Krukowskiego, Prace naukowe, Rękopis - notatki Stefana Krukowskiego o różnych stanowiskach (Zbrza Wielka, Domaniewice, Złota, Działoszyn, okolice Ojcowa, Polany) oraz o znaleziskach zwierząt plejstoceńskich, sygn. PL PMA 1-1-1-62-45.

18 Sprawozdanie z działalności Prezydjum, s. 223-224.

19 W efekcie kolejnych badań prowadzonych na tym stanowisku odnaleziono liczne pozostałości dużej osady, którą przypisano kulturze pucharów lejkowatych, zabytki neolitycznej kultury lendzielskiej, kultury łużyckiej z IV okresu epoki brązu oraz ślady osadnictwa wczesnośredniowiecznego, B. Balcer, Stanowisko Pieczyska (Zbrza Wielka) w Zawichoście-Podgórzu, pow. Sandomierz w świetle pierwszych wykopalisk, „Wiadomości Archeologiczne" t. 32, 1967, s. 290-375; P. Werens, Ratownicze badania wykopaliskowe w obrębie wielkiej osady neolitycznej w Zawichoście-Podgórzu w latach 2014-2015, www.archeologia-sandomierz.pl [dostęp 15.01.2019].

20 B. Balcer, op. cit. s. 293.

21 K. Ryszewska, Badania archeologiczne Zdzisława Lenartowicza w międzyrzeczu Wisły i Pilicy na przełomie XIX i XX wieku, „Kwartalnik Historii Nauki i Techniki” t. 62, 2017, nr 1, s. 29-47.

22 Z. Podkowińska, Zbiór wykopalisk Muzeum Ziemi Sandomierskiej Polskiego Towarzystwa Krajoznawczego w Sandomierzu, „Wiadomości Archeologiczne” t. 8, 1923, z. 1 s. 37-38.

23 J. Żurowski, Sprawozdanie z działalności Państwowego Urzędu Konserwatorskiego Okręgu Zachodniomałopolskiego za rok 1923, „Wiadomości Archeologiczne” t. 9, 1925, z. 3-4, s. 334.

24 M. Karczewski, op. cit., s. 186. 
1. inspekcja majątków parcelowanych przez Główny Urząd Ziemski w celu wyłączenia na rzecz państwa nieruchomych zabytków archeologicznych,

2. doraźna ochrona wykopalisk przed zniszczeniem,

3. inwentaryzacja zabytków w poszczególnych okręgach oraz

4. popularyzacja archeologii przeddziejowej i opieki nad zabytkami ${ }^{25}$.

Realizacja punktu pierwszego okazała się jednak bardzo utrudniona wobec otrzymania na nią funduszy przez konserwatorów dopiero w lipcu 1921 r., gdy parcelacja gruntów była już bardzo zaawansowana, a w niektórych wypadkach zakończona ${ }^{26}$.

Sytuacja ta skłoniła Stefana Krukowskiego do skorzystania z propozycji geologa Jana Samsonowicza (1888-1959), pracownika Państwowego Instytutu Geologicznego w Warszawie, dotyczącej podjęcia wspólnej wyprawy biegnącej doliną Wisły, między Zawichostem a ujściem rzeki Kamiennej oraz doliną tej ostatniej rzeki (Ryc. 1). Głównym jej celem była rejestracja znajdujących się tam złóż krzemienia oraz związanych z nimi stanowisk archeologicznych ${ }^{27}$. W trakcie prowadzonych w 1921 r. poszukiwań badaczom udało się zlokalizować szereg pracowni obróbki krzemienia datowanych przez Krukowskiego na okres „mikrolitu”28 i neolitu. Jedną z najbogatszych pracowni, z licznymi narzędziami wykonanymi z krzemienia pasiastego, odnaleziono w Borowni, k. Rudy Kościelnej, pow. opatowski ${ }^{29}$. Również kolejna wyprawa Krukowskiego i Samsonowicza, która objęła tereny powiatów iłżeckiego i radomskiego, przyniosła odkrycie wielu stanowisk archeologicznych ze znaleziskami z różnych okresów pradziejowych. Interesujących rezultatów dostarczyła m.in. wizyta we wsi Polany, pow. radomski, gdzie Krukowski wyróżnił dwa stanowiska charakteryzujące się występowaniem dużej liczby wyrobów wykonanych z krzemienia czekoladowego ${ }^{30}$. Szczególnie wartościowym plonem poszukiwań obu badaczy była dokonana wówczas lokalizacja złóż krzemienia czekoladowego w okolicach Iłży, Seredzic, Polan, Wierzbicy, Orońska ${ }^{31}$.

25 Sprawozdanie z działalności Państwowego Grona Konserwatorów Zabytków Przedhistorycznych w r. 1921, „Wiadomości Archeologiczne” t. 6, 1921, s. 142.

26 J. Żurowski, Sprawozdanie z działalności Państwowego Urzędu Konserwatorskiego na Okręg Krakowski „Wiadomości Archeologiczne" t. 6, 1921, s. 169.

27 S. Krukowski, Sprawozdanie z działalności Państwowego Urzędu Konserwatorskiego na Okręg WarszawskiPołudniowy, „Wiadomości Archeologiczne” t. 6, 1921, s. 157-164.

28 Mikrolitem Krukowski określał końcowy etap starszego okresu epoki kamienia (paleolitu) i środkowy okres epoki kamienia (mezolit) charakteryzujące się wytwarzaniem drobnych, czyli mikrolitycznych narzędzi krzemiennych.

29 S. Krukowski, Sprawozdanie z działalności Państwowego Urzędu Konserwatorskiego na Okręg Warszawski-Południowy, s. 163. Nowsze badania wykazały, że odkryta przez Krukowskiego pracownia leżała na powierzchni kopalni krzemienia pasiastego najprawdopodobniej funkcjonującej głównie we wczesnej epoce brązu, J. Lech, Stefan Krukowski i początki badań nad pradziejowym górnictwem krzemienia w Polsce (1919-1939), [w:] Profesor Stefan Krukowski (1890-1982). Działalność archeologiczna i jej znaczenie dla nauki polskiej, red. J. Lech, J. Partyka, Ojców 1992, s. 143; idem, Archeologiczne badania wykopaliskowe prehistorycznej kopalni krzemienia „Borownia” w Rudzie Kościelnej, krzemionki.pl/aktualnosci/archeologiczne-badania-wykopaliskowe-prehistorycznej-kopalni-krzemienia-borownia-w-rudzie-koscielnej [dostęp: 20.02.2019]

30 S. Krukowski, Sprawozdanie z działalności Państwowego Urzędu Konserwatorskiego na Okręg Kielecki w r. 1922, „Wiadomości Archeologiczne” t. 8, 1923, z. 1, s. 68-69. Wyróżniono tu później kilka stanowisk (miejsc eksploatacji krzemienia oraz pracowni jego obróbki) z paleolitu schyłkowego, z neolitu oraz z wczesnej epoki brązu, R. Schild, Lokalizacja prahistorycznych punktów eksploatacji krzemienia czekoladowego na NE obrzeżeniu Gór Świętokrzyskich, „Folia Quaternaria” 1971, nr 39, s. 30-34; J. Budziszewski, Stan badań nad występowaniem i pradziejową eksploatacją krzemieni czekoladowych, [w:] Krzemień czekoladowy w pradziejach, red. W. Borkowski, J. Libera, B. Sałacińska, S. Sałaciński, Warszawa-Lublin 2008, s. 68-72.

31 S. Krukowski, Sprawozdanie z działalności Państwowego Urzędu Konserwatorskiego na Okręg Kielecki, s. 6970. 


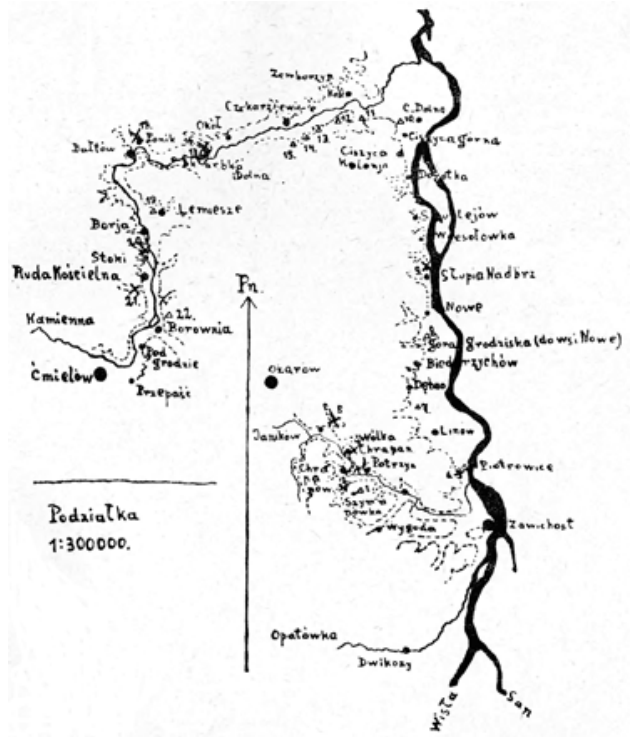

Ryc. 1. Szlak wyprawy Stefana Krukowskiego i Jana Samsonowicza z 1921 r. wiodący doliną Wisły i Kamiennej, za: S. Krukowski, Sprawozdanie z działalności Państwowego Urzędu Konserwatorskiego na Okręg Warszawski-Południowy, Rys. 10.
Celem kilkuletnich badań Krukowskiego i Samsonowicza (1921-1927), była Góra Puławska, pow. kozienicki, z bardzo interesującym górnopaleolitycznym stanowiskiem archeologicznym ${ }^{32}$, odkrytym i zbadanym w latach 1893-1895 r. przez rosyjskiego bibliotekarza i geologa Nikolaja Josifoviča Krištafoviča ${ }^{33}$, uznanym przez Krukowskiego za „wyjątkowo doniosłe [...] pod względem geologicznym i prahistorycznym"34. Samsonowicz podczas prowadzonych $w$ tym miejscu badań geologicznych odkrył trzy ogniska paleolityczne pochodzące z tej samej warstwy kulturowej, co wcześniejsze znaleziska Krištafoviča ${ }^{35}$. Podjęta przez Krukowskiego ich analiza archeologiczna wykazała, że zachowane in situ ogniska składały się z drobnych okruchów i pyłu z węgla drzewnego, a na ich obrzeżach występowały ułamki i negatywy połupanych kości zwierzęcych oraz wyroby krze-

mienne w liczbie przeszło stu egzemplarzy ${ }^{36}$. Zabytki z tego stanowiska częściowo zachowane w zbiorach Państwowego Muzeum Archeologicznego w Warszawie (dalej PMA), zostały po latach przeanalizowane przez Elżbietę Sachse-Kozłowską i Adama Nowaka ${ }^{37}$.

W trakcie swojej działalności konserwatorskiej Stefan Krukowski kilkakrotnie odwiedzał kolonię Krzemionki, pow. opatowski, gdzie Jan Samsonowicz podczas badań geologicznych prowadzonych w $1922 \mathrm{r}$. odkrył kopalnię krzemienia pasiastego ${ }^{38}$. W tym samy roku Krukowski „zwiedził [...] pobieżnie powierzchnie kopalni i mało podziemi”"39. Archeolog trafnie zinterpretował stanowisko jako pochodzące $z$ okresu neolitu i nie czując się kompetentnym w badaniach stanowisk $z$ tego okresu zdecydował się nie podejmować tam wykopalisk. Zawiadomił o znalezisku prezydium PGKZP, postulując wysłanie do przebadania

32 Idem, Sprawozdanie z działalności Państwowego Urzędu Konserwatorskiego na Okręg Warszawski-Południowy, s. 166-167; idem, Paleolit, [w:] J. Kostrzewski, S. Krukowski, R. Jakimowicz, Prehistoria ziem polskich. Encyklopedia Polska, t. 4, cz. 1, Kraków 1939-1948, s. 38-69.

33 S. J. Czarnowski, Siedziba paleolityczna na Górze Puławskiej na lewym brzegu Wisły, Warszawa-Kraków 1911.

34 S. Krukowski, Kronika konserwatora zabytków przedhistorycznych za rok 1924, „Wiadomości Archeologiczne” t. 10, 1929, z. 3-4, s. 248-253.

35 S. Krukowski, J. Samsonowicz, Stanowisko górnosolutrejskie z końca następowania ostatniego zlodowacenia w Polsce, „Sprawozdania Państwowego Instytutu Geologicznego” t. 1, 1922, z. 4-6, s. 405-444.

36 S. Krukowski, Kronika konserwatora, s. 248-253; ZC PMA, Spuścizna Stefana Krukowskiego, Prace naukowe, Rękopis pracy prof. Stefana Krukowskiego pt.: „O stanowisku paleolitycznym w Górze Puławskiej”, sygn. PL PMA 1-1-1-1-17.

37 A. Nowak, Materiały krzemienne z oryniackiego stanowiska w Górze Puławskiej, „Acta Universitatis Nicolai Copernici" t. 34, 2015, s. 84-104.

38 J. Samsonowicz, O złożach krzemieni w utworach jurajskich północno-wschodniego zbocza Gór Świętokrzyskich, „Wiadomości Archeologiczne” t. 8, 1923, z. 1-2, s. 22-23.

39 S. Krukowski, Krzemionki Opatowskie, Warszawa 1939, s. 113. 
obiektu „badaczy robiących w neolicie”. Podkreślił przy tym wielką wartość kopalni jako bardzo dobrze zachowanego „zabytku nieruchomego [o charakterze] krajobrazu górniczego i wyrobisk podziemnych skalnych" i potrzebę ustanowienia z niej rezerwatu ${ }^{40}$. Ponowną wizytę w Krzemionkach Krukowski odbył w 1923 r. w towarzystwie Zygmunta Szmita. Obaj badacze zebrali wówczas z powierzchni stanowiska „kilka skrzyń wyrobów krzemiennych nakopalnianych" potrzebnych im jako „materiał porównawczy” przy powierzchniowych badaniach „kopalni przedhistorycznych innego wieku"41. Kolejnym badaczem Krzemionek został konserwator okręgu zachodnio-małopolskiego Józef Żurowski, który udał się tam w związku z doniesieniami Jana Samsonowicza oraz członków Oddziału PTK w Ostrowcu informującymi o zagrożeniu stanowiska przez rabunkową eksploatację wapienia ${ }^{42}$. Podjęte przez konserwatora prace badawcze zostały sfinansowane przez wspomniany oddział PTK ${ }^{43}$. W trakcie badań powierzchniowych konserwator „zaznajomił się [...] ogólnie z obszarem całej kopalni [...] z jej położeniem, z wyglądem i rozmieszczeniem studnisk" (szybów). Podejmując wykopaliska archeolog odgruzował siedem chodników na przestrzeni około $60 \mathrm{~m}$, badając powierzchnię ich ścian, rozmieszczenie i kształt filarów oporowych oraz rozważając sposoby i kierunki eksploatacji krzemienia przez prehistorycznych górników. Oczyszczono także jeden z nienaruszonych dotąd szybów i kolejne przylegające doń chodniki (Ryc. 2), w których wypełniskach archeolog odnalazł kilkadziesiąt okazów górniczych narzędzi rogowych i kamiennych ${ }^{44}$. W 1926 r. Żurowski ponownie udał się do Krzemionek, tym razem wraz z kierownikiem PGKZP Romanem Jakimowiczem, celem dokonania wspólnych oględzin kopalni. Efektem tej wizyty był „memoriał”, w którym konserwatorzy zawarli ocenę stanu zachowania stanowiska, wniosek o jego wpisanie do rejestru zabytków oraz projekt utworzenia na obszarze kopalni rezerwatu wraz z określeniem jego zasięgu ${ }^{45}$. Ponadto na prośbę kierownika PGKZP Starosta Opatowski wydał zakaz pozyskiwania na tym terenie wapienia, a na polecenie Okręgowego Urzędu Górniczego opieczętowano cztery nielegalne kamieniołomy założone w prehistorycznych szybach ${ }^{46}$. Pomimo to wydobycie wapienia w Krzemionkach nadal trwało ${ }^{47}$, a jego wynikiem było m.in. zniszczenie szybów i chodników oczyszczonych przez Żurowskiego ${ }^{48}$. W 1928 r., ostatnim roku działalności PGKZP, Roman Jakimowicz porozumiał się z krajowym zarządem PTK, które otrzymało środki z Funduszu Kultury Narodowej przeznaczone na wykupienie części kopalni. Docelowo zamierzano rozszerzyć obszar planowanego rezerwatu archeologicznego ${ }^{49}$ poprzez odkupienie w kolej-

40 Ibid.

41 Idem, Pierwsza charakterystyka stanowiska kopalnianego Krzemionki na podstawie jego pozostałości naziemnych, „Wiadomości Archeologiczne” t. 11, 1932, s. 53; idem, Krzemionki, s. 113-114.

42 Sprawozdanie z działalności Kierownictwa Państwowego Grona Konserwatorów Zabytków Przedhistorycznych za rok 1925, „Wiadomości Archeologiczne” t. 10, 1929, s. 201.

43 M. Radwan, Przedhistoryczne kopalnie krzemienia w pow. opatowskim, „Ziemia” t. 11, 1926, nr 5, s. 69.

44 J. Żurowski, Sprawozdanie z działalności Państwowego Urzędu Konserwatorskiego Okręgu Zachodniomałopolskiego i Śląskiego za lata 1924-1926, „Wiadomości Archeologiczne” t. 10, 1929, s. 220-221.

45 lbid., s. 224.

46 Sprawozdanie z działalności Kierownictwa Państwowego Grona Konserwatorów Zabytków Przedhistorycznych za rok 1925, s. 201.

47 Sprawozdanie z działalności Kierownictwa Państwowego Grona Konserwatorów Zabytków Przedhistorycznych za rok 1926, „Wiadomości Archeologiczne” t. 10, 1929, s. 201-207.

48 S. Krukowski, Krzemionki, s. 118-119.

49 ZC PMA, Spuścizna Stefana Krukowskiego, Korespondencja, Rękopis - brudnopis pisma Stefana Krukowskiego do Kierownika PGK streszczającego naukowe powody utworzenia rezerwatu w Krzemionkach (wersja druga), sygn. PL PMA 1-1-2-43-11. 


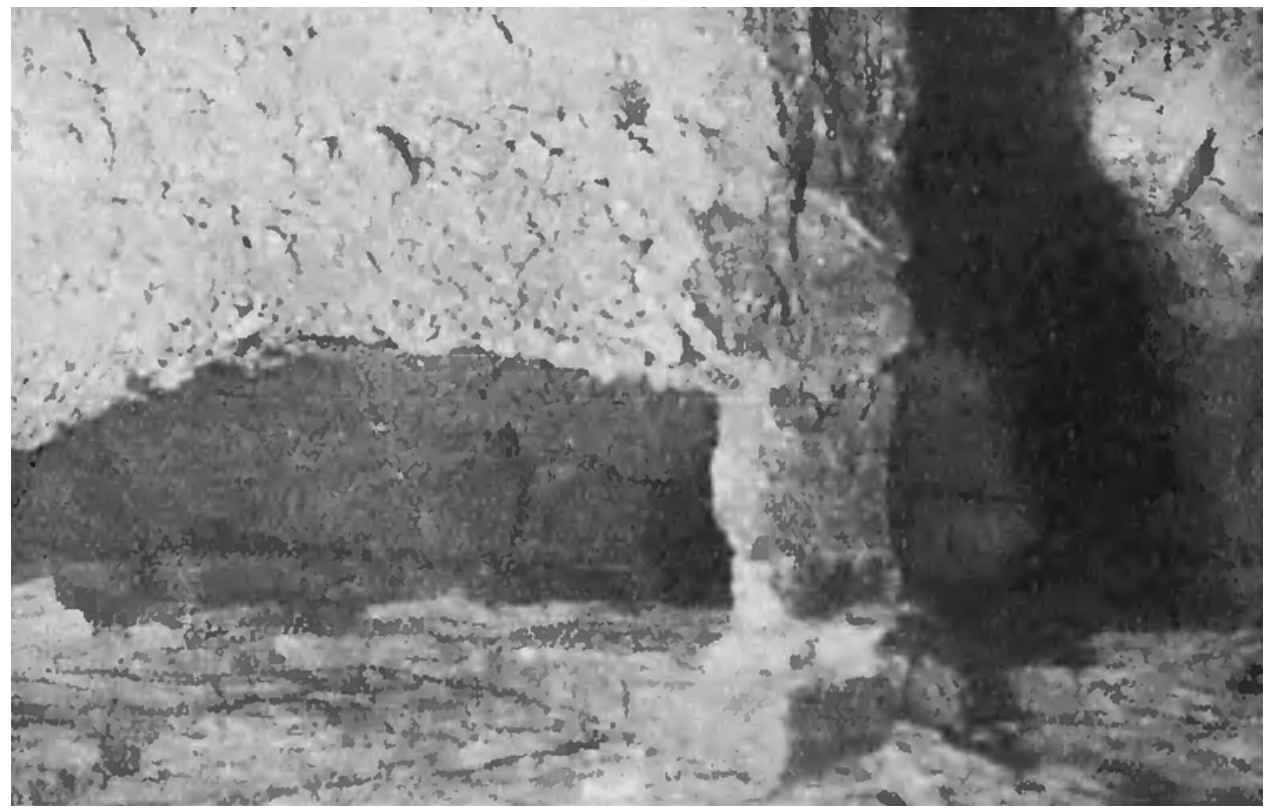

Ryc. 2. Wnętrze chodnika w kopalni w krzemionkach, fot. M. Żakowska, za: M. Radwan, Przedhistoryczne kopalnie, s. 71.

nych latach następnych części kopalni przez PMA, które przejęło znaczną część kompetencji rozwiązanego PGKZP. Tym razem do Krzemionek ponownie udał się Stefan Krukowski, który doprowadził do znacznego ograniczenia niszczycielskiej eksploatacji wapienia przez okoliczną ludność oraz do likwidacji procederu wywozu i handlu krzemieniem ${ }^{50}$. Następnie Krukowski, wcześniej odmawiający badania kopalni datowanej na okres neolitu, zdecydował się jednak na podjęcie na tym stanowisku prac archeologicznych. W omawianym tu okresie ograniczały się one do przeglądu i segregacji zwałów krzemieni i zbierania wyrobów krzemiennych z powierzchni pola górniczego. Eksplorację podziemnej części kopalni archeolog rozpoczął dopiero w następnym, $1929 \mathrm{r}^{51}$.

Jednym z najważniejszych osiągnięć Józefa Żurowskiego jako konserwatora PGKZP były badania stanowiska zlokalizowanego $1921 \mathrm{r}^{52}$ w miejscowości Książnice Wielkie, pow. pińczowski, prowadzone w latach 1922-1924. Miały one charakter ratowniczy związany z zakupieniem obszaru stanowiska pod cmentarz parafialny ${ }^{53}$. Podczas wykopalisk archeolog odsłonił sześćdziesiąt sześć jam o kolistym zarysie wypełnionych ziemią przemieszaną z fragmentami naczyń ceramicznych (w tym „czasz o kołnierzu lejowatym”), z połupanymi kośćmi zwierzęcymi i z muszlami rzecznych skójek. W ich wypełniskach

50 R. Jakimowicz, Sprawozdanie z działalności Państwowego Muzeum Archeologicznego za 1928 rok, „Wiadomości Archeologiczne" t. 13, 1935, s. 238-239.

51 S. Krukowski, Krzemionki, s. 115-120.

52 J. Żurowski, Sprawozdanie z działalności Państwowego Urzędu Konserwatorskiego na Okręg Krakowski, s. 169.

53 W Archiwum MAK zachowały się pisma, podpisane przez wiceprezesa PGKZP Włodzimierza Antoniewicza, skierowane do Ks. Dziekana Józefa Latera i organisty Władysława Waszkiewicza, zawierające podziękowania za udostępnienie terenów pod wykopaliska (przez tego drugiego) oraz pomoc w ich przeprowadzeniu (przez ks. Latera), Archiwum MAK, Katalog stanowisk, Teczka Książnice Wielkie, Pismo do W. Szan. Pana Władysława Waszkiewicza z dn. 17 X 1922 r., Pismo do Ks. Dziekana Józefa Latera z dn. 17 X 1922 r. 
znaleziono także wyroby krzemienne (noże, siekierki, groty strzał łuku) i kościane, przęśliki, ciężarki do sieci oraz pozostałości palenisk ${ }^{54}$. Jamy te archeolog zinterpretował jako ziemianki „mieszkalne względnie odpadkowe” stanowiące pozostałość neolitycznej osady55. Bardzo interesującym odkryciem okazało się ujawnienie, w obrębie dwunastu spośród odkrytych jam, odchodzących od nich w bok nisz grobowych, zawierających pochówki szkieletowe. Zmarli, pochowani w pozycji skurczonej na boku, zostali wyposażeni w naczynia ceramiczne zdobione odciskami sznura (Ryc. 3), narzędzia krzemienne, kamienne i kościane oraz wisiorki wykonane z muszli ${ }^{56}$. Pomimo, że ceramika z jam różniła się od naczyń z grobów niszowych, to badacz mylnie uznał, że są one sobie współczesne i reprezentują tą samą kulturę archeologiczną, którą w kolejnych publikacjach nazywał "małopolską"57. Materiały z wykopalisk w Książnicach Wielkich niestety nie doczekały się całościowego opracowania przez Żurowskiego. Po latach tego zadania w odniesieniu do materiałów z osady neolitycznej podjęły się Barbara Burchard i Anna Eker, natomiast analizy dwunastu odkrytych przez Żurowskiego pochówków niszowych dokonał Jan Machnik ${ }^{58}$.

Oprócz reliktów osadnictwa z okresu neolitu Żurowski odkrył także w Książnicach Wielkich oraz w pobliskich Jaksicach pozostałości wczesnośredniowiecznych cmentarzysk "rzędowych". Podjęte przezeń wykopaliska przyniosły odkrycie trzynastu pochówków szkieletowych w Książnicach i dwudziestu jeden grobów w Jaksicach. Ich skromne wyposażenie stanowiły małe żelazne nożyki, kabłączki skroniowe i nieliczne naczynia ceramiczne, ponadto $w$ jednym z grobów w Jaksicach znaleziono leżącą koło czaszki zmarłego połówkę monety „denara niemieckiego, bitego z początku XI wieku”. Archeolog przypisał cmentarzyska plemieniu Wiślan, a dokładniej ich „gałęzi zachodniej”, czyli „Krakowianom" i datował je na XI w. ${ }^{59}$

Kolejnym ważnym odkryciem konserwatora dokonanym w Majkowicach, w pow. miechowskim, było odnalezienie pochówku szkieletowego z zachowanym wyposażeniem w postaci fragmentu krzemiennego noża i ceramiki, w tym „kubka” z dużym uchem. Zdaniem archeologa znalezisko stanowiło pierwszy odkryty na ziemiach polskich grób kultury ceramiki promienistej ${ }^{60}$, której Żurowski poświęcił także osobną publikację ${ }^{61}$.

54 J. Żurowski, Sprawozdanie z działalności Państwowego Urzędu Konserwatorskiego na Okręg Zachodniomałopolski za r. 1922, „Wiadomości Archeologiczne” t. 8, 1923, z. 1, s. 94-96.

55 Idem, Sprawozdanie z działalności Państwowego Urzędu Konserwatorskiego Okręgu Zachodniomałopolskiego, s. 335.

56 Idem, Sprawozdanie z działalności Państwowego Urzędu Konserwatorskiego na Okręg Zachodniomałopolski, s. 95-97.

57 Idem, Sprawozdania z działalności Państwowego Urzędu Konserwatorskiego Okręgu Zachodniomałopolskiego i Śląskiego, s. 218; J. Zabłocki, J. Żurowski, Znalezienie zapasów Lithospermum w dwu stanowiskach kultury małopolskiej, „Materiały Prehistoryczne” t. 1, 1934, s. 1-27.

58 Według ich ustaleń osada i groby nie należały do tej samej kultury archeologicznej, tę pierwszą założyła ludność kultury „czasz" (pucharów) lejkowatych, a cmentarzysko - ludność również neolitycznej, lecz przybyłej na te tereny później - kultury ceramiki sznurowej, B. Burchard, A. Ekier, Osada kultury czasz lejowatych w Książnicach Wielkich, pow. Kazimierza Wielka, [w:] Studia i Materiały do badań nad neolitem Małopolski, red. S. Nosek, Wrocław 1964, s. 191-285; J. Machnik, Groby kultury ceramiki sznurowej w Książnicach Wielkich, pow. Kazimierza Wielka, [w:] Studia i Materiały do badań nad neolitem Małopolski, red. S. Nosek, Wrocław 1964, s. 339-341.

59 J. Żurowski, Wiślanie-Krakowianie doby wczesnohistorycznej w świetle wykopalisk archeologicznych lat ostatnich, „Sprawozdania z Czynności i Posiedzeń Polskiej Akademii Umiejętności” t. 31, 1925, nr 10, s. 13-16.

60 Idem, Sprawozdanie z działalności Państwowego Urzędu Konserwatorskiego Okręgu Zachodniomałopolskiego, s. 337.

61 Idem, Problem kultury ceramiki promienistej, „Wiadomości Archeologiczne” t. 12, 1932, s. 139-167. 

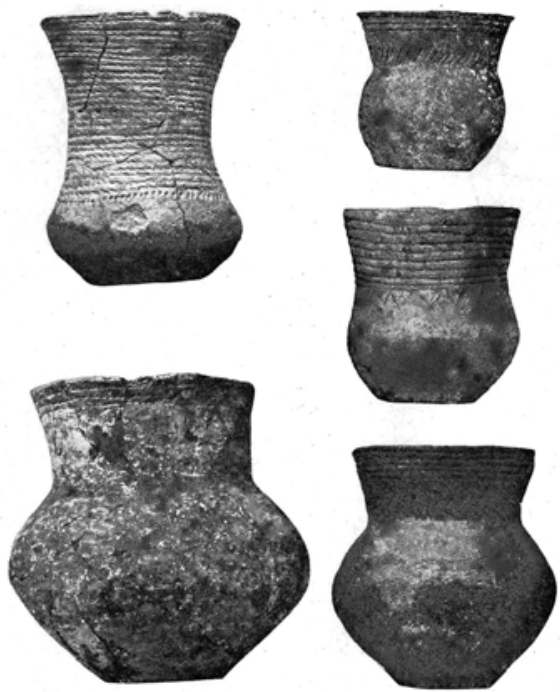

Ryc. 3. Naczynia ceramiczne z grobów niszowych w Książnicach Wielkich, fot. J. Żurowski, za: J. Żurowski, Sprawozdania z działalności Państwowego Urzędu Konserwatorskiego Okręgu Zachodniomałopolskiego i Śląskiego, tabl. XLVII.
W 1922 r. obaj konserwatorzy, których działalność obejmowała tereny województwa kieleckiego, czyli Stefan Krukowski i Józef Żurowski, na polecenie prezydium PGKZP podjęli czynności zmierzające do objęcia ochroną i zabezpieczenia przed dewastacją jaskiń Jury Ojcowskiej. Jaskinie tego regionu, wielokrotnie już we wcześniejszych latach eksploatowano gospodarczo, ze względu na przydatność ich namulisk do produkcji nawozów. Kolejne zagrożenie pojawiło się, gdy w grudniu 1921 r. Jan Podczaski, pełnomocnik ówczesnych właścicieli dóbr ojcowskich Czartoryskich, zawarł umowę o eksploatację jaskiń z Towarzystwem Przedsiębiorstw Górniczych SA (Tepege) z Krakowa62. Kontrakt ten zawarto bez wiedzy i zgody władz konserwatorskich, nie zważając na zabytkową rangę ojcowskich jaskiń jako stanowisk archeologicznych od lat znanych i niejednokrotnie badanych ${ }^{63}$. Akcja protestacyjna konserwatorów PGKZP przyniosła pozytywny skutek i już w lutym 1922 r. umowa z Tepege została rozwiązana ${ }^{64}$. Pojawiały się jednak następne zagrożenia, takie jak powzięty w 1924 r. projekt przeprowadzenia szosy poprzez położony w jej obrębie Wąwóz Jamki, obfitujący w bardzo liczne stanowiska archeologiczne. Dzięki akcji Grona, reprezentowanego w tej sprawie przez jego honorowego konserwatora profesora Demetrykiewicza, udało się ów projekt zablokować. Następnym krokiem podjętym przez kierownictwo PGKZP, było powierzenie Józefowi Żurowskiemu zadania wpisania „najważniejszych jaskiń” regionu do Państwowego Inwentarza Zabytków65. Żurowski wytypował dwanaście jaskiń Jury Ojcowskiej: Okopy Wielką, Okopy Górną, Ciemną, Łokietka, Krowią, Dziurawiec, Wylotną, Zbójecką, Złodziejską, Piętrową, Krakowską i Białą, stanowiących, jego zdaniem, najwartościowsze stanowiska archeologiczne, które ostatecznie wpisano do Państwowego Inwentarza Zabytków na mocy orzeczenia Rady Konserwatorów z 29 października 1924 r. ${ }^{66}$

62 Sprawozdanie z działalności Prezydjum, s. 224; B. J. Janusz, Sprawozdanie z działalności Państwowego Konserwatora Zabytków Przedhistorycznych na Okręg Lwowski, „Wiadomości Archeologiczne” t. 10, 1929, s. 261-262; S. Nosek, Zarys historii badań archeologicznych w Małopolsce, Wrocław 1967, s. 108.

63 K. Ryszewska, Historia badań archeologicznych na obszarze międzyrzecza Wisły i Pilicy w XIX i na początku wieku, Kielce 2013, s. 88-110, 149-157, 214-216; Jura Ojcowska w pradziejach i początkach państwa polskiego, red. J. Lech, J. Partyka, Ojców 2006.

64 Sprawozdanie z Il konferencji konserwatorów okręgowych odbytej w Poznaniu w dniu 11-13 marca 1922 r., „Wiadomości Archeologiczne" t. 7, 1922, s. 156; Nosek, op. cit.

65 Sprawozdanie z działalności Kierownictwa Państwowego Grona Konserwatorów Zabytków Przedhistorycznych za rok 1924, „Wiadomości Archeologiczne” t. 10, 1929, s. 184, 187-188; M. Drewko, Protokół VII Konferencji Konserwatorów Okręgowych Zabytków Prehistorycznych odbytej dn. 18 i 19 grudnia 1924 r. w Warszawie, „Wiadomości Archeologiczne” t. 10, 1929, s. 191.

66 J. Żurowski, Sprawozdania z działalności Państwowego Urzędu Konserwatorskiego Okręgu Zachodniomałopolskiego i Śląskiego, s. 215-216. 
W 1925 r. do kierownictwa PGKZP dotarły informacje o zamierzonej parcelacji majątku państwowego w Złotej, pow. sandomierski, pochodzące od odkrywcy kompleksu stanowisk w Złotej Zdzisława Lenartowicza oraz od delegata PGKZP z Sandomierza Józefa Pietraszewskiego. Ten ostatni przeprowadził w Złotej prace ratownicze, badając pojedynczy grób odsłonięty podczas orki na polu „Nad Wawrem"67. Następnie do Złotej delegowano Józefa Żurowskiego który stwierdził występowanie na obszarze złockich pól „bardzo ważnych, różnego wieku i typu stanowisk" i zbadał kolejne dwa pochówki odkryte na polu „Nad Wawrem"68. Jego wniosek o wstrzymanie lub uchylenie parcelacji, poparty przez kierownictwo PGKZP, przyniósł skutek i parcelacja została wstrzymana69. Wykopaliska na tym stanowisku kontynuowano w 1926 r. Odkryto wówczas pochówki „eneolityczne”, w tym pojedynczy grób zwierzęcy i piętnaście grobów ludzkich, bogato wyposażonych w ceramikę, narzędzia krzemienne i kościane, ozdoby z bursztynu, muszli oraz zęby i kości zwierzęce oraz trzy wczesnośredniowieczne groby szkieletowe ${ }^{70}$. W tym samym roku podjęto $w$ Złotej badania na stanowisku „Gajowizna”, początkowo prowadzone przez Zygmunta Szmita, a następnie przez Romana Jakimowicza71. W ich efekcie odkryto cmentarzysko z pochówkami ludzkimi, w większości szkieletowymi, oraz z grobami zwierzęcymi (Ryc. 4), przeważnie zbiorowymi i wielogatunkowymi 72 . Odkrywcy cmentarzyska „na Gajowiźnie” trafnie powiązali je z „epoką neolityczną"73. Nie dokonali jednak opracowania zabytków z tego stanowiska, ani nie przeprowadzili jego dokładniejszej interpretacji. Materiały z omawianych wykopalisk, zachowane w zbiorach PMA, zostały opracowane dopiero po wielu latach przez Zygmunta Krzaka ${ }^{74}$.

W 1927 r. kierownictwu Grona udało się powstrzymać projekt tymczasowego wydzierżawienia pól Złotej kilkudziesięciu przyszłym parcelantom, a także zapewnić możliwość corocznego wyznaczenia obszaru o pow. 4 ha przeznaczonego na prace wykopaliskowe. Ówczesne badania obejmujące pole „Nad Wawrem” zostały przeprowadzone przez Szmita i Żurowskiego korzystających z pomocy Tadeusza Reymana i studenta UJ Gabriela Leńczyka (1895-1977) ${ }^{75}$. W ich efekcie przebadano większość obszaru omawianego

67 Ibid.

68 Sprawozdanie z działalności Kierownictwa Państwowego Grona Konserwatorów Zabytków Przedhistorycznych za rok1925, s. 200-201.

69 J. Żurowski, Sprawozdanie z działalności Państwowego Urzędu Konserwatorskiego Okręgu Zachodniomałopolskiego i Śląskiego, s. 219-220.

70 R. Jakimowicz, Sprawozdanie z działalności państwowego konserwatora zabytków prehistorycznych okręgu warszawskiego za lata 1924-1926, „Wiadomości Archeologiczne” t. 10, 1929, s. 279.

71 Sprawozdanie z działalności Kierownictwa Państwowego Grona Konserwatorów Zabytków Przedhistorycznych za rok 1926, s. 205.

72 Z. Jakimowiczowa, Groby zwierzęce w Złotej pod Sandomierzem, „Z Otchłani Wieków” t. 2, 1927, z. 3, ryc. 2, s. 34-36; Z. Krzak, Cmentarzysko na Gajowiźnie pod względem archeologicznym, [w:] Cmentarzysko kultury amfor kulistych w Złotej Sandomierskiej, red. J. Kowalczyk, Wrocław 1977, s.12-63.

73 Z. Jakimowiczowa, op. cit., s. 35-36.

74 Na tej podstawie Z. Krzak zidentyfikował na „Gajowiźnie” jedenaście grobów ludzkich, dziesięć obiektów trudnych do interpretacji ze względu na „szczątkowy charakter ich zawartości” oraz czternaście „zwierzęcych jam ofiarniczych” (grobów zwierzęcych). Zdaniem Krzaka oraz kolejnych badaczy pochówki ze stanowiska „Gajowizna" (poza jednym obiektem) należą do kultury amfor kulistych, Z. Krzak, op. cit., s. 59-65. B. Kołodziej, Pochówki zwierzęce w neolicie na terenie ziem polskich, „Materiały i Sprawozdania Rzeszowskiego Ośrodka Archeologicznego" t. 32, 2011, s. 80-86.

75 Archiwum MAK, Katalog stanowisk, Teczka Złota, G. Leńczyk, Dziennik prac badawczych 1927. Brulion Złota, pow. Sandomierz. 


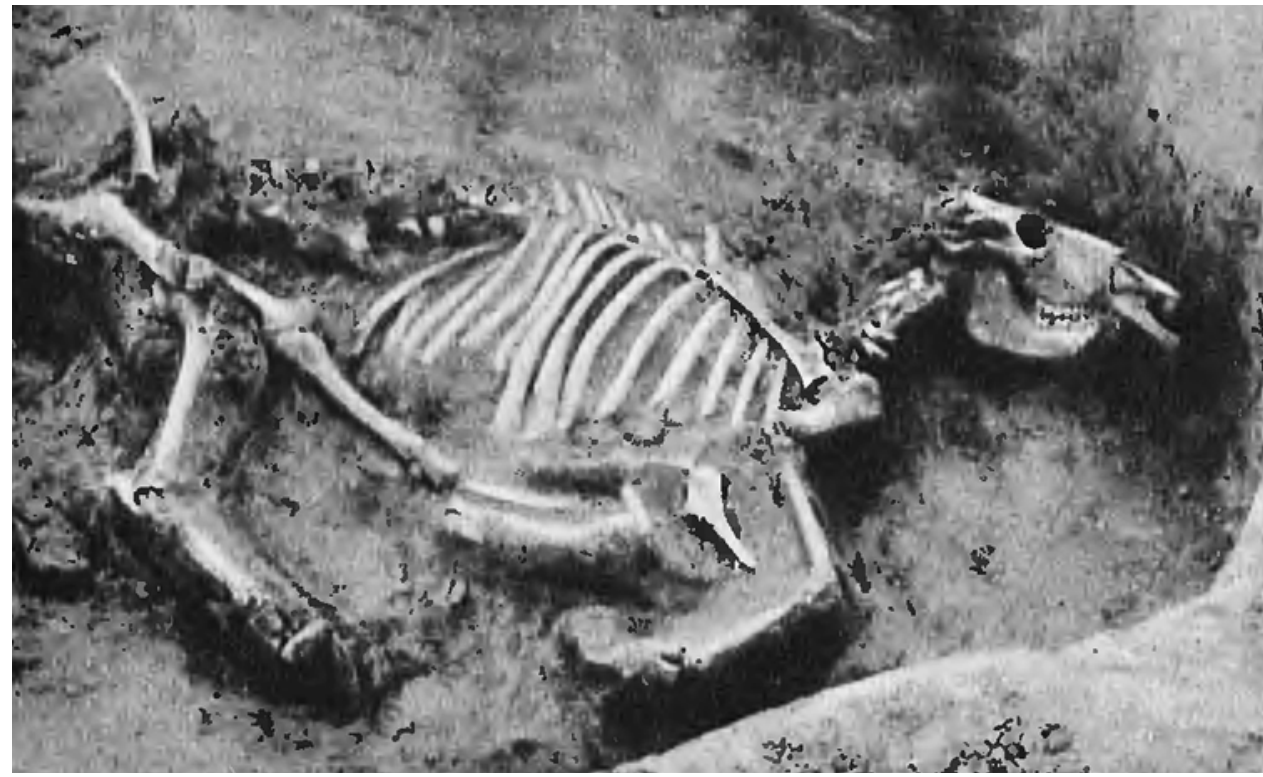

Ryc. 4. Pochówek zwierzęcy ze Złotej, fot. J. Żurowski, za: J. Żurowski, Największe badania archeologiczne w Polsce, „Kalendarz llustrowanego Kuryera Codziennego na rok 1931” r. 4, 1931, s. 98.

stanowiska76 ${ }^{76}$ dkrywając około 400 obiektów „obejmujących zabytki mieszkań ludzkich” w postaci jam oraz pochówki, w większości datowane na okres neolitu77. Żurowski, w poświęconych tym odkryciom opracowaniach, zaliczył obiekty ze stanowiska „nad Wawrem" do kilku kultur, głównie neolitycznych: ceramiki wstęgowej kłutej ${ }^{78}$, ceramiki wstęgowej malowanej ${ }^{79}$, pucharów lejkowatych, ceramiki sznurowej, złockiej (najliczniejsze, często bogato wyposażone, groby i ziemianki) ${ }^{80}$ oraz kultury pucharów dzwonowatych (pochówki). Dokładnego opracowania przez Żurowskiego doczekały jedynie te ostatnie

76 R. Jakimowicz, Sprawozdanie z działalności Państwowego Muzeum Archeologicznego za 1927 rok, „Wiadomości Archeologiczne" 1935, t. 13, s. 222; J. Żurowski, Sprawozdanie z działalności Konserwatora Zabytków Przedhistorycznych Okręgu Zachodniomałopolskiego i Śląskiego za lata 1927 i 1928, „Wiadomości Archeologiczne" t. 13, 1935, s. 286.

77 J. Żurowski, Ogólne wyniki badań archeologicznych w Złotej, pow. Sandomierz, w latach 1926-1930, „Sprawozdania z Czynności i Posiedzeń Polskiej Akademii Umiejętności" t. 39, 1934, nr 5, s. 34. Obok zabytków neolitycznych na stanowisku „Nad Wawrem” odkryto wówczas jedenaście grobów kultury mierzanowickiej z wczesnej epoki brązu oraz nieliczne pozostałości kultury trzcinieckiej z tej samej epoki; J. T. Bąbel, Cmentarzyska społeczności kultury mierzanowickiej na Wyżynie Sandomierskiej. Część I. Obrządek pogrzebowy, Rzeszów 2013, s. 19, 26.

78 J. Żurowski, Pierwsze groby kultur ceramik wstęgowych w Polsce, „Sprawozdania z Czynności i Posiedzeń Polskiej Akademii Umiejętności" t. 35, 1930, nr 6, s. 30. Dziś te obiekty łączy się z grupą samborzecko-opatowską lub kulturą malicką, B. Sałacińska, A. Zakościelna, Pierwsze groby kultur ceramik wstęgowych w Polsce. Groby kultury lubelsko-wołyńskiej ze stanowiska Złota Grodzisko I i Grodzisko I, „Wiadomości Archeologiczne” t. 59, 2007, s. 77.

79 Obecnie zabytki te przypisuje się kulturze lubelsko-wołyńskiej, B. Sałacińska, A. Zakościelna, Pierwsze groby, s. 77.

80 J Żurowski, Z badań archeologicznych w Złotej koło Sandomierza w latach 1927 i 1928, „Z Otchłani Wieków” t. 4, 1929, z. 1, s. 1-6; idem, Rzut oka na badania archeologiczne w sandomierskiem lat ostatnich, w: Sandomierskie, red. W.S. Laskowski, Sandomierz 1933, s. 5-10. 
znaleziska ${ }^{81}$. W kolejnym roku prac badawczych w Złotej Żurowski przebadał dużą część pola "Grodzisko" (stanowiska „Grodzisko I"). Badania te przyniosły odkrycie płytkich jam i licznych grobów, które przypisał kilku kulturom neolitycznym, w tym ceramiki wstęgowej malowanej i złockiej ${ }^{82}$. Konserwator odnalazł także pochówki popielnicowe kultury grobów kloszowych oraz pojedynczy pochówek szkieletowy i pozostałości zabudowy „z czasów wczesnohistorycznych"83. Ze względu na liczebność znajdujących się w Złotej stanowisk archeologicznych, ich znaczny zasięg, stan zachowania oraz ich wielkie znaczenie, szczególnie „dla poznania kultur końcowego neolitu i eneolitu na południowych obszarach Polski", dotychczasowy kierownik PGKZP Roman Jakimowicz wystąpił do władz powiatowych o odroczenie parcelacji złockich pól do $1936 \mathrm{r}^{84}$

W wyniku kolejnej informacji otrzymanej od delegata PGKZP Juliana Pietraszewskiego Żurowski odwiedził w towarzystwie tego ostatniego wieś Beradź, pow. sandomierski. Archeolog zidentyfikował odnaleziony tam grób szkieletowy wyposażony w naczynia ceramiczne typowe dla kultury pucharów dzwonowatych. Rezultatem tego odkrycia były wykopaliska przeprowadzone przez pomocnika Żurowskiego studenta prehistorii na UJ Kazimierza Salewicza (1897-1940), które przyniosły odnalezienie dwóch następnych pochówków omawianej kultury (Ryc. 5 i 6$)^{85}$. Wartość omawianego odkrycia była tym większa, że zbadane cmentarzysko było dopiero drugim stanowiskiem kultury pucharów dzwonowatych (po stanowisku „Nad Wawrem” w Złotej) odnalezionym w granicach ziem polskich ${ }^{86}$.

Kolejne badania ratownicze podjęte w ostatnim roku działalności PGKZP dotyczyły okolic kościoła św. Jakuba w Sandomierzu, gdzie podczas przygotowania terenu pod budowę domu księży emerytów doszło do dewastacji „terenu zabytkowego"87. Przeprowadzone tam wstępne prace wykopaliskowe przyniosły odkrycie dwóch pochówków neolitycznych, pięćdziesięciu grobów wczesnośredniowiecznego cmentarzyska oraz pozostałości średniowiecznej zabudowy w postaci zarysów czworokątnych budowli drewnianych o konstrukcji słupowej i towarzyszących im jam ${ }^{88}$.

Konserwatorzy i delegaci PGKZP dokonali rejestracji oraz przeprowadzili badania także wielu innych stanowisk archeologicznych na terenie województwa kieleckiego, na których wymienienie i omówienie nie pozwalają ograniczone rozmiary tego tekstu ${ }^{89}$.

Działacze Grona, w tym przede wszystkim konserwatorzy: Józef Żurowski i Stefan Krukowski prowadzili na omawianym terenie również działalność edukacyjną. Składały

81 Idem, Pierwsze ślady kultury pucharów dzwonowatych w Polsce, „Wiadomości Archeologiczne” t. 11, 1929, s. $117-124$.

82 Idem, Pierwsze groby kultur ceramik wstęgowych w Polsce II, „Sprawozdania z Czynności i Posiedzeń Polskiej Akademii Umiejętności" t. 37, 1932, nr 9, s. 30-40; idem, Ogólne wyniki badań archeologicznych w Złotej، s. 32; Z. Podkowińska, Pierwsza charakterystyka stanowiska eneolitycznego na polu Grodzisko I we wsi Złota, pow. Sandomierz, „Wiadomości Archeologiczne” t. 19, 1953, z. 1, s. 5, 44.

83 J. Żurowski, Z badań archeologicznych, s. 6-7.

84 R. Jakimowicz, Sprawozdanie z działalności Państwowego Muzeum Archeologicznego za 1928 rok, s. 238.

85 J. Żurowski, Sprawozdanie z działalności Konserwatora, s. 288; idem, Pierwsze ślady, s. 131-135.

86 Idem, Nowe odkrycia w Sandomierskiem, „Z Otchłani Wieków” t. 4, 1929, z. 2, s. 36.

87 R. Jakimowicz, Sprawozdanie z działalności Państwowego Muzeum Archeologicznego za 1928 rok, s. $265-267$.

88 J. Żurowski, Pierwsze groby, s. 30; idem, Nowe odkrycia w Sandomierskiem, s. 37; idem, Sprawozdanie z dziatalności Konserwatora, s. 289, 293.

89 Autorka przygotowuje na ten temat bardziej szczegółowe opracowanie. 

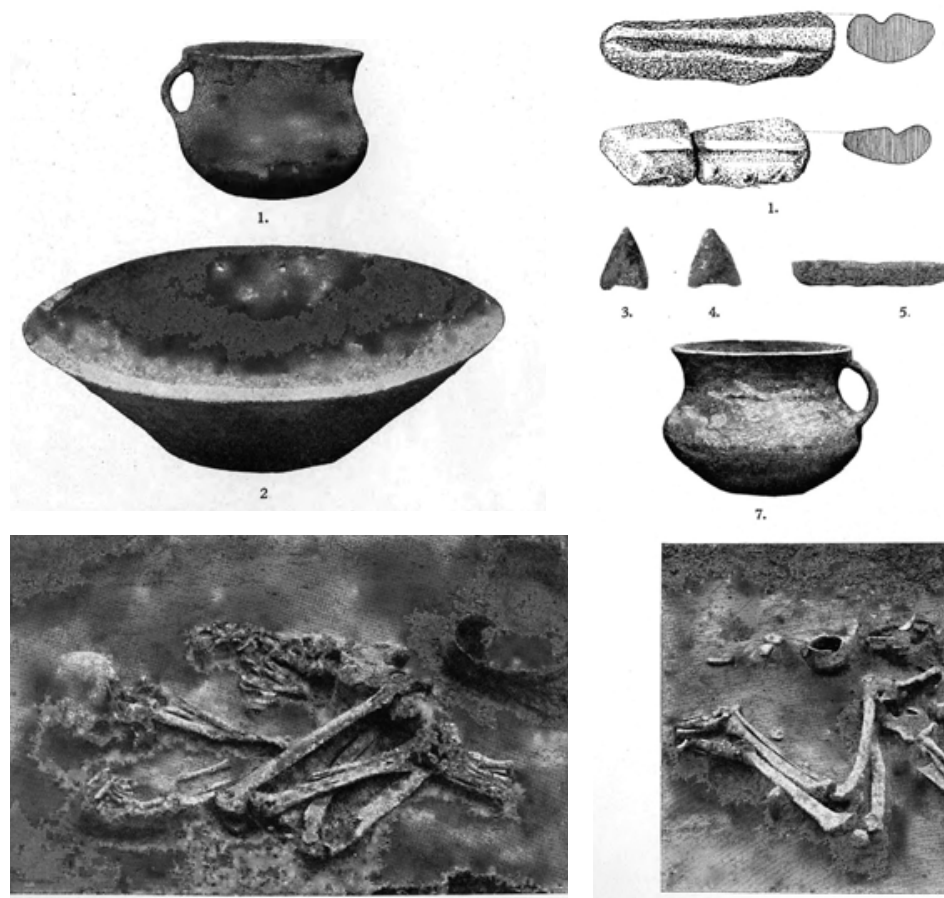

Ryc. 5. Grób kobiecy kultury pucharów dzwonowatych z Beradzi, fot. A. Pawlikowski, J. Żurowski, za: J Żurowski, Pierwsze ślady, tabl. XXVI.
1.

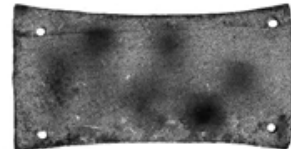

2.
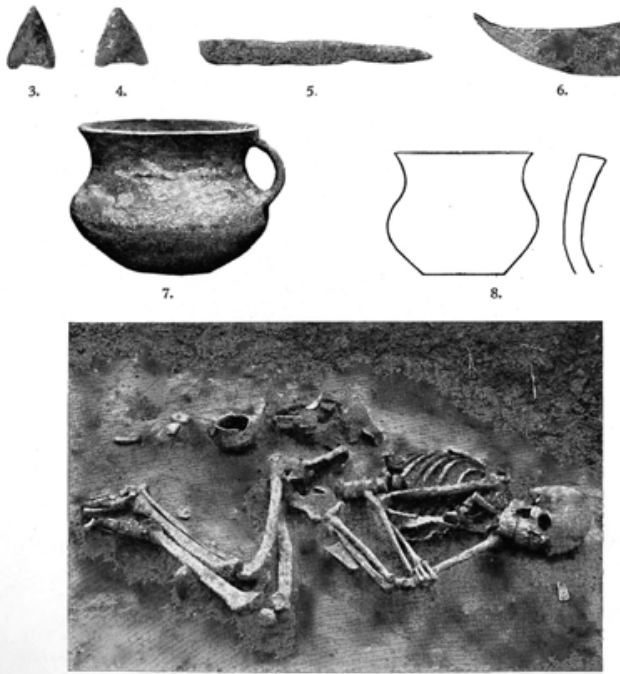

Ryc. 6. Grób męski kultury pucharów dzwonowatych z Beradzi, fot. A. Pawlikowski, J. Żurowski, za: J Żurowski, Pierwsze ślady, tabl. XXVII.

się na nią odczyty wygłaszane cyklicznie w różnych miejscowościach Kielecczyzny ${ }^{90}$ oraz wycieczki zainteresowanych „osób (z inteligencji)”91, w tym członków PTK, po wykopaliskach, przede wszystkim w Krzemionkach, w Książnicach Wielkich, w Złotej i w Sandomierzu oraz do jaskiń Jury Ojcowskiej ${ }^{92}$.

Funkcjonowanie PGKZP zakończyło Rozporządzenie Prezydenta Rzeczypospolitej z dn. 6 marca 1928 r., w którym ochronę zabytków, także archeologicznych, powierzono wojewódzkim władzom administracyjnym i powołanym przy nich konserwatorom ${ }^{93}$. Kolejnym rozporządzeniem powołano $\mathrm{PMA}^{94}$, jako instytucję centralną, nie tylko gromadzącą za-

90 ZC PMA, Spuścizna Stefana Krukowskiego, Korespondencja, Rękopis - brudnopis pisma Stefana Krukowskiego do Sekretarza Zarządu Sejmiku Powiatowego w Puławach z prośbą o wystawienie zaświadczenia o wygłoszeniu przez Krukowskiego odczytu „Co to jest archeologia przedhistoryczna i czego nas uczy?" w dniu 25 października 1025 r. w Puławach. Góra Puławska 15 XI [19]25 r. (nr pisma 36/25), sygn. PL PMA 1-1-2-12-28; A. Patkowski, Towarzystwo Krajoznawcze (1906-1931) na terenie województwa kieleckiego, [w:] Pamiętnik Świętokrzyski 1930, red. A. Patkowski, Kielce 1931, s. 392.

91 J. Żurowski, Sprawozdanie z działalności Konserwatora, s. 291.

92 Ibid., s. 289, 291; idem, Sprawozdanie z działalności Państwowego Urzędu Konserwatorskiego Okręgu Zachodniomałopolskiego i Śląskiego, „Wiadomości Archeologiczne” 1929, t. 10, s. 222; Archiwum MAK, Teczka Książnice Wielkie, Notatnik Józefa Żurowskiego, notatka z 28-29 VII 1922 r.

93 Rozporządzenie Prezydenta Rzeczypospolitej z dnia 6 marca 1928 r. o opiece nad zabytkami, „Dziennik Ustaw RP" z 14 III 1928 r., nr 29, poz. 265.

94 Instrukcja Ministra Wyznań Religijnych i Oświecenia Publicznego z dnia 2 czerwca 1930 roku wydana w porozumieniu z Ministrem Spraw Wewnętrznych o prawach i obowiązkach konserwatorów, jako fachowych organów wojewódzkich władz administracji ogólnej, „Monitor Polski” z 9 III 1930 r., nr 156, poz. 239. 
bytki, lecz także patronującą badaniom stanowisk archeologicznych na obszarze całej Polski, mającą w sprawach związanych z ochroną i konserwacją zabytków prehistorycznych współpracować z konserwatorami wojewódzkimi ${ }^{95}$.

\section{Podsumowanie}

Działalność PGKZP na obszarze całego kraju, w tym na Kielecczyźnie, należy ocenić bardzo pozytywnie. Pracujący na terenie województwa kieleckiego konserwatorzy okręgowi w ciągu niecałych dziewięciu lat swojej pracy uczynili wiele dla inwentaryzacji oraz ochrony stanowisk i zabytków archeologicznych na Kielecczyźnie. Zasługi ich były tym większe, że przyszło im pracować w niełatwych warunkach, a zlecane im przez Kierownictwo PGKZP zadania obejmowały wiele form działalności. Trudności w wypełnianiu licznych obowiązków związane były m.in. z rozległością powierzonych ich pieczy okręgów. Kolejny problem wynikał z faktu, iż odkrywane i rejestrowane stanowiska oraz zabytki pochodziły z wszystkich epok prehistorycznych oraz z czasów historycznych (średniowiecza), a kompetencje konserwatorów do ich identyfikacji oraz prowadzenia prac badawczych były różne. Niewątpliwie osobą dobrze przygotowaną do tak wymagających zadań był Józef Żurowski, którego atutem było specjalistyczne wykształcenie w zakresie prehistorii i zdobywane kolejno stopnie naukowe. Kompetencje te umożliwiały mu prowadzenie badań na stanowiskach archeologicznych pochodzących z różnych epok i pozwalały mu je na ogół trafnie interpretować. Żurowski był przy tym człowiekiem bardzo obowiązkowym, który skrupulatnie realizował wszystkie zadania powierzane konserwatorom, prowadząc także działania edukacyjne. Archeolog sporządzał również, na ogół, staranną dokumentację opisową, rysunkową i fotograficzną badanych stanowisk. Pozyskiwane zabytki oraz dokumentację z wykopalisk przekazywał do zbiorów Muzeum Archeologicznego PAU, dopiero część okazów odnalezionych podczas ostatniego roku pracy jako konserwatora ofiarował do zbiorów powołanego w 1928 r. PMA ${ }^{96}$. Coraz szerzej z roku na rok prowadzone badania wykopaliskowe dostarczały jednak takich ilości informacji oraz materiału zabytkowego, że na jego systematyczne opracowanie, interpretację i publikację tak zajętemu badaczowi nie starczało czasu. Szansy tej Józefa Żurowskiego ostatecznie pozbawił los, gdyż ten ogromnie zasłużony archeolog zmarł przedwcześnie w 45 roku życia.

Zgoła inne były kwalifikacje i losy zawodowe Stefana Krukowskiego. Ów niezwykle uzdolniony badacz - samouk specjalizował się w badaniach najstarszego okresu epoki kamienia. Stąd unikał zajmowania się stanowiskami i zabytkami młodszymi od paleolitycznych, co nie było najlepszą kwalifikacją dla objęcia funkcji konserwatora okręgowego zobowiązanego do inwentaryzacji wszelkich znalezisk archeologicznych. W przypadkach konieczności podejmowania badań ratowniczych na stanowiskach z młodszych okresów i epok Krukowski starał się to zadanie scedować na innych, bardziej w tej materii kompetentnych badaczy. W piśmie z 20 marca 1923 r. skierowanym do Prezydium PGKZP, Krukowski deklarował: 
nie mogę przeprowadzać badań terenowych (rozkopywań) obiektów protohistorycznych (wiek brązu, żelaza i wczesnohistoryczne. Zawiadomienie to składam pragnąc zadokumentować dwa analogiczne ustne oświadczenia poczynione na konferencjach II z r. 1922 (w Warszawie) i I z r. b. (w Warszawie) ${ }^{97}$.

W rezultacie prace wykopaliskowe na terenie podległego Krukowskiemu okręgu prowadzili także inni archeolodzy, w tym najczęściej Józef Żurowski oraz kierownik PGKZP od 1924 r. Roman Jakimowicz. Niemniej działalność Krukowskiego jako konserwatora okręgu kieleckiego przyniosła bardzo wartościowe rezultaty, szczególnie dzięki przeprowadzonym we współpracy z Janem Samsonowiczem poszukiwaniom miejsc występowania, eksploatacji i obróbki surowców użytkowanych przez społeczności pradziejowe.

Należy również docenić zasługi konserwatorów PGKZP dla ochrony szeregu stanowisk archeologicznych w omawianym regionie, w tym m.in. jaskiń Jury Ojcowskiej, stanowisk w Złotej, oraz kopalni w Krzemionkach. Badania, tej ostatniej, kontynuowane także w kolejnych latach przez Stefana Krukowskiego, zaowocowały bardzo wartościową monografią tego wyjątkowego stanowiska archeologicznego ${ }^{98}$.

Niezależnie od merytorycznych kwalifikacji i indywidualnych preferencji, praca działających na Kielecczyźnie konserwatorów napotykała na podobne trudności, których doświadczali zresztą wszyscy konserwatorzy PGKZP, dysponujący zbyt ograniczonymi środkami i niewystarczającymi możliwościami dla zabezpieczenia wszelkich znalezisk i poprowadzenia pilnych prac badawczych. Część z odkrytych w omawianym tu okresie stanowisk archeologicznych, m.in. w Złotej i w Krzemionkach, badano także w latach następnych. W wielu jednak wypadkach powracano na nie dopiero po wielu, czasem nawet kilkudziesięciu latach, co dotyczyło również opracowania dużej części materiałów zabytkowych pozyskanych przez konserwatorów PGKZP i szczęśliwie zachowanych z zbiorach PMA i Muzeum Archeologicznego w Krakowie. Działania konserwatorów okręgowych uzupełniali delegaci PGKZP, którzy także podejmowali rozmaite prace na rzecz ochrony zabytków, a niekiedy prowadzili badania powierzchniowe i wykopaliskowe o charakterze ratunkowym. Pożyteczne efekty przynosiła również współpraca PGKZP z lokalnymi miłośnikami archeologii oraz regionalnymi stowarzyszeniami - oddziałami PTK, z których najbardziej aktywne były: odział w Sandomierzu oraz Odział w Ostrowcu, szczególnie zaangażowany, także finansowo, w ratowanie kopalni w Krzemionkach.

Reasumując, pomimo wszystkich trudności, przeszkód i ograniczeń, czasy działalności PGKZP na terenie województwa kieleckiego były niewątpliwie bardzo owocnym okresem w historii badań archeologicznych w tym regionie, a odkryte i zarejestrowane wówczas stanowiska są do tej pory przedmiotem zainteresowania i badań archeologów.

97 ZC PMA, Spuścizna Stefana Krukowskiego, Korespondencja, Rękopis pisma Stefana Krukowskiego do Prezydjum Państwowego Grona Konserwatorów Zabytków Przedhistorycznych, do Konferencyj Konserwatorów Okręgowych Zabytków Przedhistorycznych oraz do Wydziału Nauki Ministerstwa Wyznań Religijnych i Oświecenia Publicznego z odmową przeprowadzenia badań terenowych obiektów protohistorycznych (nr pisma KZPO Kiel. N 5/23), sygn. PL PMA 1-1-2-12-21.

98 S. Krukowski, Krzemionki. 


\section{Bibliografia}

\section{Źródła archiwalne}

Archiwum Muzeum Archeologicznego w Krakowie:

Katalog stanowisk: Teczka Książnice Wielkie: Notatnik Józefa Żurowskiego; Pismo do W. Szan. Pana Władysława Waszkiewicza z dn. 17 X 1922 r.; Pismo do Ks. Dziekana Józefa Latera $z$ dn. $17 \times 1922 \mathrm{r}$.

Katalog stanowisk: Teczka Złota: G. Leńczyk, Dziennik prac badawczych 1927. Brulion Złota, pow. Sandomierz.

Spuścizna Józefa Żurowskiego: Wykopalisko z Jakuszowic Małych na tle zabytków krajów ościennych [maszynopis].

Spuścizna Tadeusza Reymana: Przebieg życia [maszynopis].

Zbiory cyfrowe Państwowego Muzeum Archeologicznego w Warszawie:

Spuścizna Stefana Krukowskiego:

Korespondencja, Maszynopis - kopia pisma Państwowego Grona Konserwatorów Zabytków Przedhistorycznych (nr 191/21) do Józefa Pietraszewskiego z informacją o mianowaniu go Delegatem PGKZP na terenie województwa kieleckiego. Warszawa 21 XII 1921 r., sygn. PL PMA 1-1-2-12-8.

Korespondencja, Rękopis - brudnopis pisma Stefana Krukowskiego do Kierownika PGK streszczającego naukowe powody utworzenia rezerwatu w Krzemionkach (wersja druga), sygn. PL PMA 1-1-2-43-11.

Korespondencja, Rękopis - brudnopis pisma Stefana Krukowskiego do Sekretarza Zarządu Sejmiku Powiatowego w Puławach z prośbą o wystawienie zaświadczenia o wygłoszeniu przez Krukowskiego odczytu „Co to jest archeologia przedhistoryczna i czego nas uczy?" w dniu 25 października 1025 r. w Puławach. Góra Puławska 15 XI [19]25 r. (nr pisma 36/25), sygn. PL PMA 1-1-2-12-28.

Korespondencja, Rękopis pisma Stefana Krukowskiego do Prezydjum Państwowego Grona Konserwatorów Zabytków Przedhistorycznych, do Konferencyj Konserwatorów Okręgowych Zabytków Przedhistorycznych oraz do Wydziału Nauki Ministerstwa Wyznań Religijnych i Oświecenia Publicznego z odmową przeprowadzenia badań terenowych obiektów protohistorycznych (nr pisma KZPO Kiel. N 5/23), sygn. PL PMA 1-1-2-12-21.

Prace naukowe, Rękopis - notatki Stefana Krukowskiego o różnych stanowiskach (Zbrza Wielka, Domaniewice, Złota, Działoszyn, okolice Ojcowa, Polany) oraz o znaleziskach zwierząt plejstoceńskich, sygn. PL PMA 1-1-1-62-45.

Prace naukowe, Rękopis pracy prof. Stefana Krukowskiego pt.: „O stanowisku paleolitycznym w Górze Puławskiej", sygn. PL PMA 1-1-1-1-17.

\section{Źródła drukowane}

Rozporządzenie Prezydenta Rzeczypospolitej z dnia 6 marca 1928 r. o opiece nad zabytkami, „Dziennik Ustaw RP” z 14 III 1928 r., nr 29, poz. 265.

Instrukcja Ministra Wyznań Religijnych i Oświecenia Publicznego z dnia 2 czerwca 1930 r. wydana w porozumieniu z Ministrem Spraw Wewnętrznych o prawach i obowiązkach konserwatorów, jako fachowych organów wojewódzkich władz administracji ogólnej, „Monitor Polski” z 9 VII 1930 r., nr 156, poz. 239. 


\section{Literatura przedmiotu}

Abramowicz A., Historia archeologii polskiej. XIX i XX wiek, Warszawa-Łódź 1991.

Balcer B., Stanowisko Pieczyska (Zbrza Wielka) w Zawichoście-Podgórzu, pow. Sandomierz $w$ świetle pierwszych wykopalisk, „Wiadomości Archeologiczne” t. 32, 1967, s. 290-375.

Bąbel J.T., Cmentarzyska społeczności kultury mierzanowickiej na Wyżynie Sandomierskiej. Część I. Obrządek pogrzebowy, Rzeszów 2013.

Blombergowa M.M., Opieka nad zabytkami archeologicznymi w Polsce do roku 1928, [w:] Tadeusz Roman Żurowski i konserwatorstwo archeologiczne w Polsce XX wieku, red. J. Wysocki, Z. Kobyliński, Warszawa 1999, s. 115-131.

Budziszewski J., Stan badań nad występowaniem i pradziejową eksploatacją krzemieni czekoladowych, [w:] Krzemień czekoladowy w pradziejach, red. W. Borkowski, J. Libera, B. Sałacińska, S. Sałaciński, Warszawa-Lublin 2008, s. 33-104.

Burchard B., Ekier A., Osada kultury czasz lejowatych w Książnicach Wielkich, pow. Kazimierza Wielka, [w:] Studia i Materiały do badań nad neolitem Małopolski, red. S. Nosek, Wrocław 1964, s. 191-285

Czarnowski S.J., Siedziba paleolityczna na Górze Puławskiej na lewym brzegu Wisły, Warszawa-Kraków 1911.

Drewko M., Protokół VII Konferencji Konserwatorów Okręgowych Zabytków Prehistorycznych odbytej dn. 18 i 19 grudnia 1924 r. w Warszawie, „Wiadomości Archeologiczne” t. 10,1929 , s. $190-199$.

Jakimowicz R., Sprawozdanie z działalności państwowego konserwatora zabytków prehistorycznych okręgu warszawskiego za lata 1924-1926, „Wiadomości Archeologiczne” t. 10,1929 , s. 271-280.

Jakimowicz R., Sprawozdanie z działalności Państwowego Muzeum Archeologicznego za 1927 rok, „Wiadomości Archeologiczne” t. 13, 1935, s. 213-232.

Jakimowicz R., Sprawozdanie z działalności Państwowego Muzeum Archeologicznego za 1928 rok, "Wiadomości Archeologiczne” t. 13, 1935, s. 238-239.

Jakimowicz R., Ś. p. Józef Żurowski, „Wiadomości Numizmatyczno-Archeologiczne” t. 17, 1935 , s. 137-142.

Jakimowiczowa Z., Groby zwierzęce w Złotej pod Sandomierzem, „Z Otchłani Wieków” t. 2, 1927, z. 3, s. 33-37.

Janusz B., Sprawozdanie z działalności Państwowego Konserwatora Zabytków Przedhistorycznych na Okręg Lwowski, „Wiadomości Archeologiczne” t. 10, 1929, s. 255-270.

Jaskanis J., Wspomnienie o Zygmuncie Szmicie (1895-1929) - asystencie Państwowego Muzeum Archeologicznego w Warszawie, "Światowit” t. 42, 1999, s. 88-91.

Jura Ojcowska w pradziejach i początkach państwa polskiego, red. J. Lech, J. Partyka, Ojców 2006.

Karczewski M., Państwowe Grono Konserwatorów Zabytków Archeologicznych i Państwowe Muzeum Archeologiczne $i$ ich rola w ochronie zabytków archeologicznych, „Seminare" t. 36, 2015, nr 4, s. 183-197.

Kołodziej B., Pochówki zwierzęce w neolicie na terenie ziem polskich, „Materiały i Sprawozdania Rzeszowskiego Ośrodka Archeologicznego" t. 32, 2011, s. 80-86.

Kostrzewski J., Wspomnienie o doc. Józefie Żurowskim, "Z Otchłani Wieków" t. 27, 1961, s. 34-36. 
Kozłowski S.K., Muzeum, [w:] Stefan Krukowski i jego przygoda z PMA, red. S.K. Kozłowski, Warszawa-Łódź 2014, s. 19-57.

Kozłowski S.K., Stefan Krukowski. Narodziny giganta, Warszawa 2007.

Krukowski S., Kronika konserwatora zabytków przedhistorycznych za rok 1924, „Wiadomości Archeologiczne" t. 10, 1929, z. 3-4, s. 238-254.

Krukowski S., Krzemionki Opatowskie, Warszawa 1939.

Krukowski S., Paleolit, w: J. Kostrzewski, S. Krukowski, R. Jakimowicz, Prehistoria ziem polskich. Encyklopedia Polska, t. 4, cz. 1, Kraków 1939-1948, s. 1-117.

Krukowski S., Pierwsza charakterystyka stanowiska kopalnianego Krzemionki na podstawie jego pozostałości naziemnych, „Wiadomości Archeologiczne” t. 11, 1932, s. 5356.

Krukowski S., Sprawozdanie z działalności Państwowego Urzędu Konserwatorskiego na Okręg Kielecki w r. 1922, „Wiadomości Archeologiczne” t. 8, 1923, z. 1, s. 64-83.

Krukowski S., Sprawozdanie z działalności Państwowego Urzędu Konserwatorskiego na Okręg Warszawski-Południowy, „Wiadomości Archeologiczne” t. 6, 1921, s. 156166.

Krukowski S., Samsonowicz J., Stanowisko górnosolutrejskie z końca następowania ostatniego zlodowacenia w Polsce, „Sprawozdania Państwowego Instytutu Geologicznego" t. 1, 1922, z. 4-6, s. 405-444.

Krzak Z., Cmentarzysko na Gajowiźnie pod względem archeologicznym, w: Cmentarzysko kultury amfor kulistych w Złotej Sandomierskiej, red. J. Kowalczyk, Wrocław 1977, s. $12-63$.

Lech J., Stefan Krukowski i początki badań nad pradziejowym górnictwem krzemienia w Polsce (1919-1939), [w:] Profesor Stefan Krukowski (1890-1982). Działalność archeologiczna i jej znaczenie dla nauki polskiej, red. J. Lech, J. Partyka, Ojców 1992, s. 129-161.

Machnik J., Groby kultury ceramiki sznurowej w Książnicach Wielkich, pow. Kazimierza Wielka, w: Studia i Materiały do badań nad neolitem Małopolski, red. S. Nosek, Wrocław 1964, s. 339-341.

Nosek S., Zarys historii badań archeologicznych w Małopolsce, Wrocław 1967.

Nowak A., Materiały krzemienne z oryniackiego stanowiska w Górze Puławskiej, "Acta Universitatis Nicolai Copernici" t. 34, 2015, s. 84-104.

Organizacja ochrony zabytków przedhistorycznych w Polsce, „Wiadomości Archeologiczne" t. 5, 1920, z. 1-2, s. 77.

Patkowski A., Towarzystwo Krajoznawcze (1906-1931) na terenie województwa kieleckiego, [w:] Pamiętnik Świętokrzyski 1930, red. A. Patkowski, Kielce 1931, s. 383-395.

Podkowińska Z., Pierwsza charakterystyka stanowiska eneolitycznego na polu Grodzisko I we wsi Złota, pow. Sandomierz, „Wiadomości Archeologiczne” t. 19, 1953, z. 1, s. 1-53.

Podkowińska Z., Zbiór wykopalisk Muzeum Ziemi Sandomierskiej Polskiego Towarzystwa Krajoznawczego w Sandomierzu, „Wiadomości Archeologiczne” t. 8, 1923, z. 1, s. 2848.

Projekt rozporządzenia ministra w sprawie utworzenia Państwowego Grona Konserwatorów Zabytków Prehistorycznych, „Wiadomości Archeologiczne” t. 5, 1920, z. 1-2, s. 78-81. 
Radwan M., Przedhistoryczne kopalnie krzemienia w pow. opatowskim, „Ziemia” t. 11, 1926, nr 5, s. 69-72.

Ryszewska K., Badania archeologiczne Zdzisława Lenartowicza w międzyrzeczu Wisły i Pilicy na przełomie XIX i XX wieku, „Kwartalnik Historii Nauki i Techniki” t. 62, 2017, nr 1, s. 29-47.

Ryszewska K., Historia badań archeologicznych na obszarze międzyrzecza Wisły i Pilicy w XIX i na początku wieku, Kielce 2013.

Sałacińska B., Zakościelna A., Pierwsze groby kultur ceramik wstęgowych w Polsce. Groby kultury lubelsko-wołyńskiej ze stanowiska Złota Grodzisko I i Grodzisko I, „Wiadomości Archeologiczne" t. 59, 2007, s. 77-114.

Samsonowicz J., O złożach krzemieni w utworach jurajskich północno-wschodniego zbocza Gór Świętokrzyskich, „Wiadomości Archeologiczne” t. 8, z. 1-2, 1923, s. 17-24.

Schild R., Lokalizacja prahistorycznych punktów eksploatacji krzemienia czekoladowego na NE obrzeżeniu Gór Świętokrzyskich, „Folia Quaternaria” 1971, nr 39, s. 1-60.

Stolpiak B., Rozwój prahistorii polskiej w okresie 20-lecia międzywojennego. Część I: 1918-1928, Poznań 1984.

Sprawozdanie z działalności Prezydjum Państwowego Grona Konserwatorów Zabytków Prehistorycznych w r. 1920, „Wiadomości Archeologiczne” t. 5, 1920, z. 3-4, s. 222-227.

Sprawozdanie z działalności Kierownictwa Państwowego Grona Konserwatorów Zabytków Przedhistorycznych za rok 1924, „Wiadomości Archeologiczne” t. 10, 1929, s. 184-188.

Sprawozdanie z Działalności Kierownictwa Państwowego Grona Konserwatorów Zabytków Przedhistorycznych za rok 1925, „Wiadomości Archeologiczne” t. 10, 1929, s. 200-203.

Sprawozdanie z działalności Kierownictwa Państwowego Grona Konserwatorów Zabytków Przedhistorycznych za rok 1926, „Wiadomości Archeologiczne” t. 10, 1929, s. 205-212.

Sprawozdanie z działalności Państwowego Grona Konserwatorów Zabytków Przedhistorycznych w r. 1921, „Wiadomości Archeologiczne” t. 6, 1921, s. 142-144.

Sprawozdanie z II konferencji konserwatorów okręgowych odbytej w Poznaniu w dniu 11-13 marca 1922 r., „Wiadomości Archeologiczne” t. 7, 1922, s. 155-157

Sprawozdanie z III Konferencji konserwatorów okręgowych, odbytej w Warszawie w dn. 24 i 25 czerwca 1922 r., „Wiadomości Archeologiczne” t. 7, 1922, s. 158-160.

Tymczasowe Okręgi Konsenwatorskie, „Wiadomości Archeologiczne” t. 5, 1920, z. 1-2, s. 83. Tymczasowy skład Państwowego Grona Konserwatorów Zabytków Przedhistorycznych, „Wiadomości Archeologiczne” t. 5, 1920, z. 1-2, s. 82.

Wrońska J., Początki działalności naukowej prof. Stefana Krukowskiego, [w:] Prof. Stefan Krukowski (1890-1982): Działalność archeologiczna i jej znaczenie dla nauki polskiej, red. J. Partyka, J. Lech, Ojców 1992, s. 41-57.

Wysocki J., Konserwatorstwo archeologiczne w Polsce w latach 1920-1940, [w:] Tadeusz Roman Żurowski i konserwatorstwo archeologiczne w Polsce XX wieku, red. J. Wysocki, Z. Kobyliński, Warszawa 1999, s 133-145.

Zabłocki, J., Żurowski J., Znalezienie zapasów Lithospermum w dwu stanowiskach kultury małopolskiej, "Materiały Prehistoryczne” t. 1, 1934, s. 1-27. 
Załuska K., Historia Muzeum w Sandomierzu, „Rocznik Muzeum Świętokrzyskiego” t. 5, 1968, s. 9-28.

Żurowski J., Nowe odkrycia w Sandomierskiem, „Z Otchłani Wieków” t. 4, 1929, z. 2, s. 36-38.

Żurowski J., Ogólne wyniki badań archeologicznych w Złotej, pow. Sandomierz, w latach 1926-1930, „Sprawozdania z Czynności i Posiedzeń Polskiej Akademii Umiejętności” t. 39, 1934, nr 5, s. 31-34.

Żurowski J., Pierwsze groby kultur ceramik wstęgowych w Polsce, "Sprawozdania z Czynności i Posiedzeń Polskiej Akademii Umiejętności" t. 35, 1930, nr 6, s. 25-31.

Żurowski J., Pierwsze groby kultur ceramik wstęgowych w Polsce II, "Sprawozdania z Czynności i Posiedzeń Polskiej Akademii Umiejętności" t. 37, 1932, nr 9, s. 30-40.

Żurowski J., Pierwsze ślady kultury pucharów dzwonowatych w Polsce, "Wiadomości Archeologiczne" t. 11, 1929, s. 117-124.

Żurowski, Problem kultury ceramiki promienistej, „Wiadomości Archeologiczne” t. 12, 1932, s. 139-167.

Żurowski J., Rzut oka na badania archeologiczne $w$ sandomierskiem lat ostatnich, w: Sandomierskie, red. W.S. Laskowski, Sandomierz 1933, s. 5-10.

Żurowski J., Sprawozdanie z działalności Konserwatora Zabytków Przedhistorycznych Okręgu Zachodniomałopolskiego i Śląskiego za lata 1927 i 1928, „Wiadomości Archeologiczne" t. 13, 1935, s. 284-294.

Żurowski J., Sprawozdanie z działalności Państwowego Urzędu Konserwatorskiego na Okręg Krakowski „Wiadomości Archeologiczne” t. 6, 1921, s. 169-180.

Żurowski J., Sprawozdanie z działalności Państwowego Urzędu Konserwatorskiego na Okręg Zachodniomałopolski za R. 1922, „Wiadomości Archeologiczne” t. 8, 1923, z. 1, s. 84-99.

Żurowski J., Sprawozdanie z działalności Państwowego Urzędu Konserwatorskiego Okręgu Zachodniomałopolskiego i Śląskiego za lata 1924-1926, „Wiadomości Archeologiczne" t. 10, 1929, s. 215-229.

Żurowski J., Sprawozdanie z działalności Państwowego Urzędu Konserwatorskiego Okręgu Zachodniomałopolskiego za rok 1923, „Wiadomości Archeologiczne” t. 9, 1925, z. 3-4, s. 331-341.

Żurowski J., Wiślanie-Krakowianie doby wczesnohistorycznej w świetle wykopalisk archeologicznych lat ostatnich, „Sprawozdania z Czynności i Posiedzeń Polskiej Akademii Umiejętności" t. 31, 1925, nr 10, s. 13-16.

Żurowski J., Z badań archeologicznych w Złotej koło Sandomierza w latach 1927 i 1928, „Z Otchłani Wieków” t. 4, 1929, z. 1, s. 1-6.

\section{Strony internetowe}

Lech J., Archeologiczne badania wykopaliskowe prehistorycznej kopalni krzemienia „Borownia" w Rudzie Kościelnej, krzemionki.pl/aktualnosci/archeologiczne-badania-wykopaliskowe-prehistorycznej-kopalni-krzemienia-borownia-w-rudzie-koscielnej [dostęp 20.02.2019]. 
Werens P., Ratownicze badania wykopaliskowe w obrębie wielkiej osady neolitycznej w Zawichoście-Podgórzu w latach 2014-2015, www.archeologia-sandomierz.pl [dostęp 15.01.2019]

dr hab. Katarzyna Ryszewska, prof. UJK, archeolog i historyk. Absolwentka archeologii w Uniwersytecie Mikołaja Kopernika w Toruniu. Doktor nauk humanistycznych w zakresie archeologii. Doktor habilitowany nauk humanistycznych w zakresie historii Polski XIX w. Autorka publikacji dotyczących archeologii średniowiecza, historii obyczajów w Polsce w XIX w. oraz historii polskiej archeologii w XIX i XX w. Pracownik Instytutu Historii Uniwersytetu Jana Kochanowskiego w Kielcach.

e-mail: kryszewska@ujk.edu.pl

Data zgłoszenia artykułu: 13 marca 2019

Data przyjęcia do druku: 24 czerwca 2019 